\title{
TK 3.0 - A NYILVÁNOS ARCHÍVUM
}

Székely I ván

szekelyi@ceu.edu

D O I : 10.20520/JEL - KEP.2020.3.65

\begin{abstract}
Absztrakt
A Tömegkommunikációs Kutatóközpont, későbbi nevén Magyar Közvéleménykutató Intézet fennállása alatt számottevő belső szabadsággal, de korlátozott nyilvánossággal működő intézmény volt. Az MKI 1991-es felszámolásakor az adminisztratív iratai az Országos Levéltárba kerültek, ám az 1970-es és 80-as évek médiafogyasztását, közvéleményét, gazdasági közhangulatát egyedülálló részletességgel tükröző - addig csak korlátozottan megismerhető kutatási dokumentációját selejtezésre szánták. Ez a pótolhatatlan dokumentum- és adathagyaték kalandos fordulatok révén elöször az MTA-ELTE Kommunikációelméleti Kutatócsoporthoz, majd ennek megszünése után a Blinken OSA Archívumhoz került, amely fizikailag és intellektuálisan rendezve, részletesen leírva, segédletekkel ellátva nyilvánosan kutathatóvá tette. A tanulmány bemutatja a dokumentáció hányattatott útját, rendezésének, leírásának szempontjait, végül a kutatás ösztönzése érdekében rövid gyakorlati útmutatót nyújt az OSA online katalógusának használatához.
\end{abstract}

\section{Kulcsszavak}

Tömegkommunikációs Kutatóközpont, Magyar Közvéleménykutató Intézet, Blinken OSA Archívum, fondstruktúra, adatrekonstruálás, online katalógus

\section{TK 3.0 - THE OPEN ARCHIVE}

\section{I ván S z ékely}

\section{Abstract}

The Mass Communication Research Centre (TK), later renamed the Hungarian Institute for Public Opinion Research (MKI), had operated with remarkable internal freedom but with limited publicity. When liquidating MKI in 1991, its administrative records were taken to the National Archives, however, its limited access research documentation reflecting the media consumption, public opinion, and economic mood of the 1970s and 80s was intended for destruction. This irreplaceable document and data heritage, through adventurous turns, first got to the MTA-ELTE Communication Theory Research Group, then, after the Group's liquidation, to Blinken OSA which arranged it physically and intellectually, described it in detail, completed with finding aids, and made it publicly available. This study presents the vicissitudinous fate of the documentation, the considerations of its archival arrangement and description, and, in order to encourage research, provides a brief practical guide for using OSA's online catalog.

\section{Keywords}

Mass Communication Center, Hungarian Institute for Public Opinion Research, Blinken OSA, fonds structure, data reconstruction, online catalog 


\title{
T K 3.0 \\ - A NYILVÁNOS ARCHÍVUM
}

\author{
Székely Iván
}

A címben szereplö terminus technicus, TK 3.0 - bár nem elöször szerepel nyilvános fórumokon - némi magyarázatra szorul. Amint ismeretes, az 1.0, 2.0 jelöléssel a szoftverfejlesztés, avagy az üzleti dokumentum-előállítás produktumainak „,nagy verzióit” szokás illetni; a közöttük elhelyezkedő kisebb verziókat 1.1, 1.2 és hasonló számok jelölik. Intézmények, különösen utódszervezetek életciklusára csak kiterjesztett értelemben alkalmazhatjuk ezt a megjelölést - ám itt éppen ezt tesszük, amikor a Tömegkommunikációs Kutatóközpont, valamint de facto és de jure utódszervezetei szellemi produktumainak továbbélését, végül nyilvánossá válásának folyamatát akarjuk áttekinteni. ${ }^{1}$

Ahhoz, hogy ezt a több mint fél évszázados történetet áttekintsük, szakaszhatárait meghúzhassuk, a szellemi produktumok, az intézménytörténeti dokumentumok, az adat- és irathagyatékok sorsát legalább nagy vonalakban értékelhessük, érdemes egy összefoglaló idővonalon ábrázolni a legfontosabb mérföldköveket.

$\mathrm{Az}$ 1. ábrán látható a TK elődjének, a Magyar Rádió és Televízió Közönségkutató Csoportjának 1963-as megalakulása, majd a Tömegkommunikációs Kutatóközpont létrejötte 1969-ben - ennek ötven éves évfordulójára emlékezünk most -, majd a TK stabil politikai felügyelete az MSZMP KB Agitációs és Propaganda Osztálya részéről és ugyanakkor az évek során változó állami felügyelete; önálló költségvetési szervvé avanzsálása 1985-ben; átnevezése Magyar Közvéleménykutató Intézetté (MKI) 1988-ban, azután az MKI megszüntetése 1991-ben. Még ugyanebben az évben megalakul az MTA-ELTE Kommunikációelméleti Kutatócsoportja (KKCs), amely ugyan nem jogutódja az MKI-nak, de kutatásainak folytatója és munkatársai egy részének alkalmazója; majd egy intézménytörténetileg eseménytelen időszak

1 A TK 3.0 Vásárhelyi Mária - a „verziók” létrejöttében pótolhatatlan szerepet játszó kutató és közíró - találó megnevezése, amit először a TK irathagyatékának nyilvánosan kutathatóvá válása alkalmából rendezett konferencia („TK 3.0 - avagy hazudtak-e az emberek a Kádár-rendszerben?”, 2013), majd a Wesley János Lelkészképző Főiskola „A magyar szociológia az ezredfordulón” címü konferenciáján elhangzott előadás („TK 1.0, 2.0, 3.0 - avagy egy intézmény tanulságos metamorfózisai”, Székely 2018), legutóbb pedig a TK megalakulásának 50. évfordulója alkalmából rendezett emlékülésen elhangzott előadás (a jelen írás előzménye) használt címében. 
után a KKCs leépítése és megszüntetése következett 2011-ben. 2012-ben született Vásárhelyi Mária és a Közép-európai Egyetem Nyílt Társadalom Archívum $\left(\mathrm{OSA}^{2}\right)$ között megállapodás a megmentett irathagyaték megőrzéséről, és egy év múlva már az iratok feldolgozásáról és kutathatóvá tételéről rendezett konferenciát az OSA; az utolsó mérföldkőnek ábrázolt esemény az idővonalon az OSA és a Magyar Nemzeti Levéltár Országos Levéltára között született megállapodás a TK/MKI irathagyatékának közös feldolgozásáról.

1. ábra

A TK és utódszervezetei idövonala

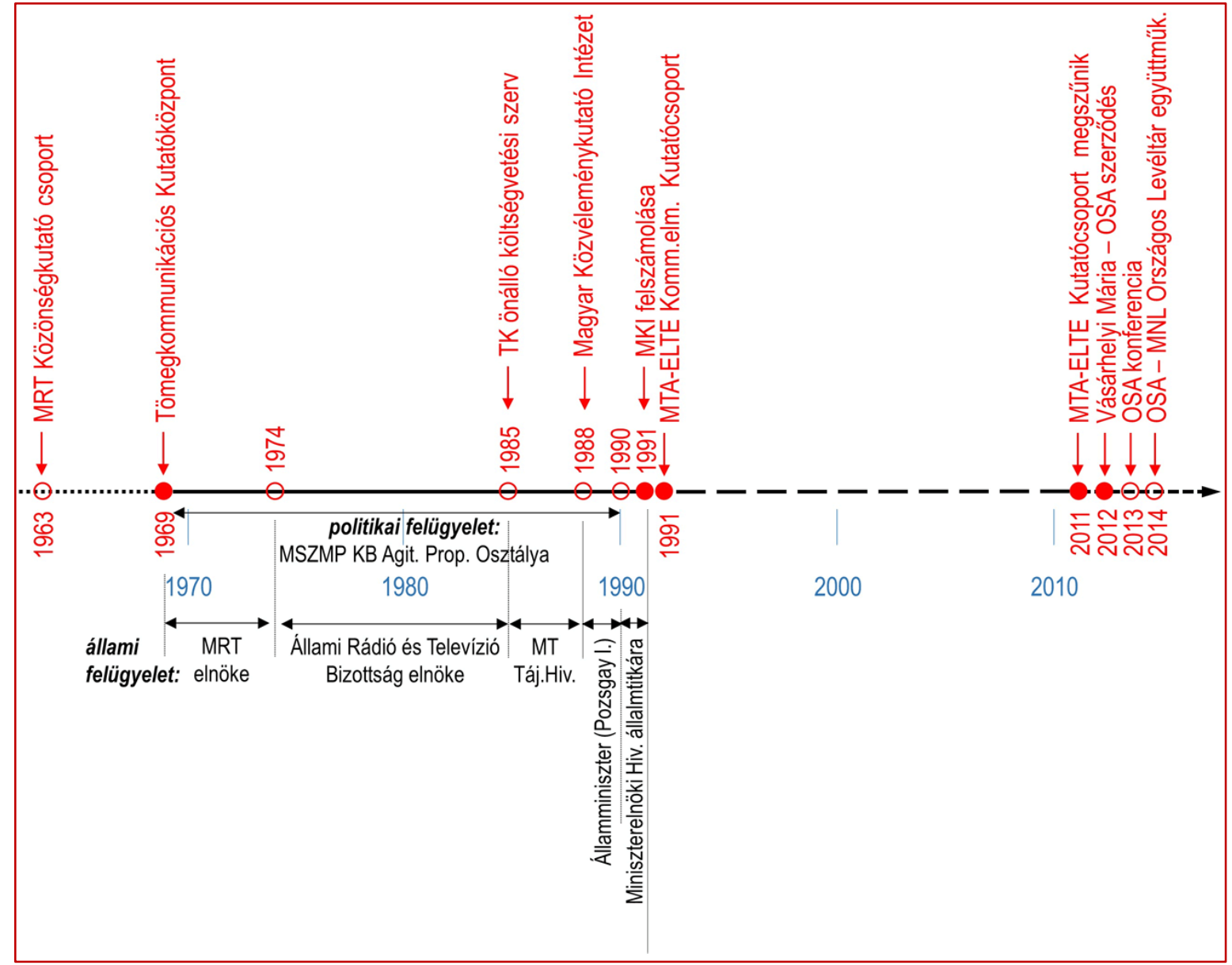

Ha nagyobb intézménytörténeti szakaszokra, „nagy verziókra” akarjuk bontani ezt a hosszú, politikailag és társadalmilag egyaránt jelentős változásokkal és megrázkódtatásokkal terhes fél évszázadot, TK 1.0 névvel illethetjük a Tömegkommunikációs Kutatóközpont megalakulásától a Magyar Közvéleménykutató Intézet megszünéséig tartó 23 éves időszakot; TK 2.0 néven nevezhetjük a KKCs megalakulásától a megszünéséig eltelt két évtizedet, és TK 3.0 nevet adhatunk annak a máig tartó időszaknak, amely az irathagyaték tartós megőrzésének és kutathatóságának történelmi szakasza, ahogy az a 2. ábrán látható.

2 Jelenlegi nevén Vera és Donald Blinken Nyílt Társadalom Archívum (röviden: Blinken OSA Archívum) 
2. ábra

Intézménytörténeti szakaszok a TK irathagyatékának kezelésében

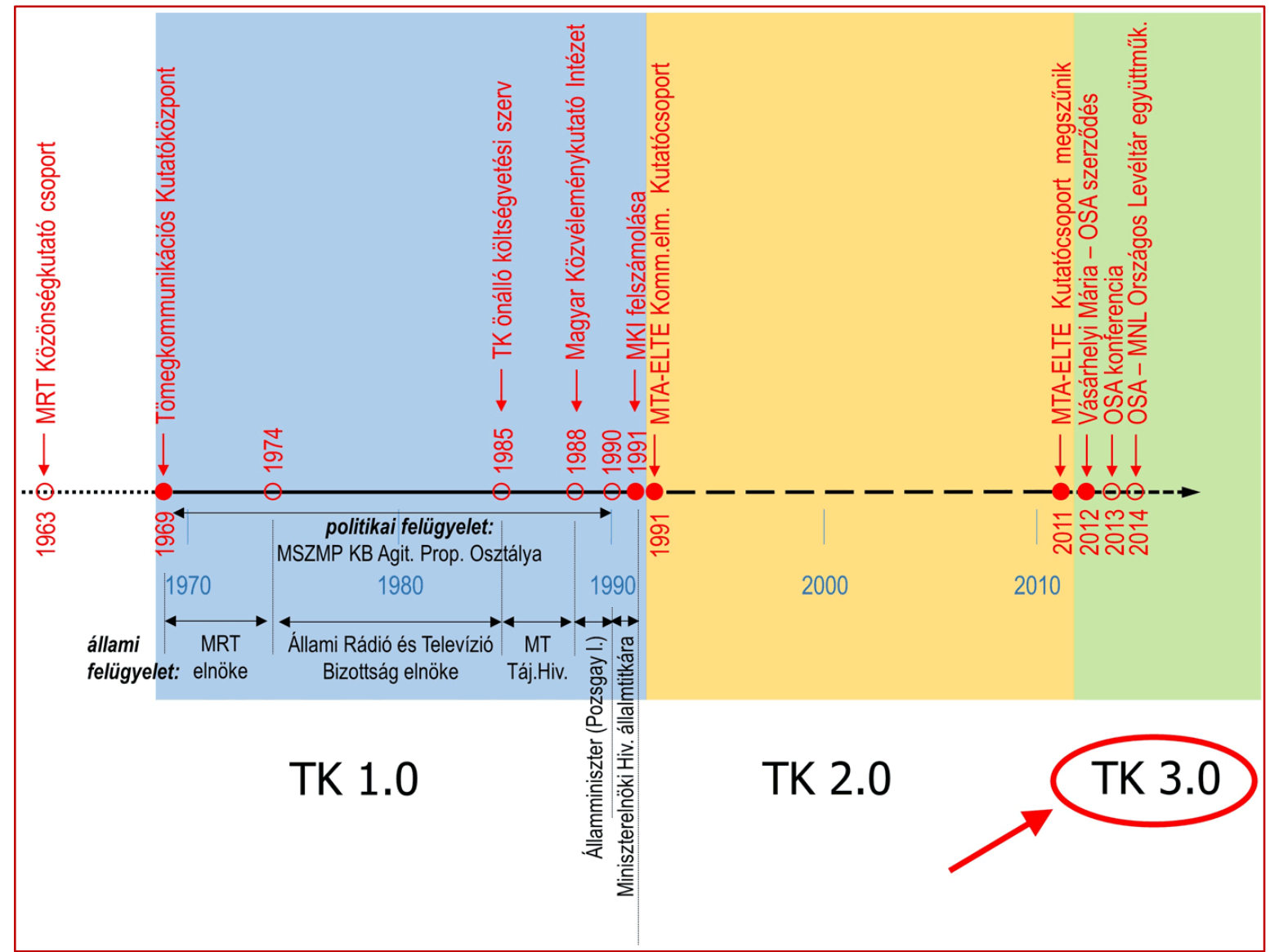

E történet legfontosabb eseményeire a következőkben röviden kitérünk, elsősorban az irathagyaték sorsa, különösen a ,verzióváltások” szempontjából.

\section{A TK irathagyatékának sorsa}

1969 és 1991 között a TK (MKI) számos szervezeti és funkcionális változáson ment keresztül, változott a neve, a jogi státusza, felépítése, kutatási portfóliója és személyi állománya, de lényegét tekintve egyetlen, folyamatos intézménytörténetet képviselő entitás maradt (Terestyéni 2009). Amikor a kormány döntött a Magyar Közvéleménykutató Intézet jogutód nélküli felszámolásáról, az intézet tárgyi, szellemi, pénzügyi vagyona és emberállománya már az erózió jeleit mutatta. Többen írtak már a munkatársak sorsáról, a nyugdíjazásukról, a KKCs állományába való átvételükről, egyetemi-kutatóintézeti elhelyezkedésükröl, a frissen alakult magán-közvéleménykutató szervezetekbe kerülésükröl; ugyancsak nem maradt feltáratlan az intézet vagyonának sorsa, privatizálása, apportként való bevitele más szervezetekbe; és az is ismert a magyar társadalomkutatók között, hogy a TK/MKI fénykorában - némi túlzással minden valamirevaló empirikus szociológus Szecskő Tamás, az intézet alapítója és vezetője köpönyegéből bújt elö, s ez a szellemi tőke megtermékenyítette az egyetemi oktatást és kutatást, de alapjául szolgált az új közvéleménykutató szervezetek szakértelmének is (Lukáts é.n.). 
Kevés szó esett azonban az intézmény irathagyatékának - vagy általánosabban: rögzített adatés dokumentumhagyatékának - sorsáról. ${ }^{3}$

Amikor a felszámolás során erőltetett ütemben kellett kiüríteni az MKI székhelyéül szolgáló (a munkatársak számára egyébként méltatlan körülményeket nyújtó, a pártállami múlt történéseivel terhelt) Akadémia utcai épületrészt - hogy az épületet megvásároló osztrák Creditanstalt mielőbb elfoglalhassa -, kivonultak az Országos Levéltár munkatársai, hogy jogszabályi kötelezettségüknek eleget téve felmérjék az országos hatáskörü, közfeladatot ellátó szerv irathagyatékát és a maradandónak ítélt iratokat a levéltárba szállítsák. Vásárhelyi Mária visszaemlékezése szerint a levéltárosok csak az egyes szervezeti egységek adminisztratív iratait (az irodák polcain és szekrényeiben, zárt fiókjaiban sorakozó hivatalos leveleket, utasításokat, jelentéseket, listákat, kimutatásokat, pénzügyi és munkáltatói dokumentumokat) tartották maradandó értékünek, a kutatási anyagokat nem. Érdekes módon egy még feldolgozás alatt álló vizsgálat több mint 1.000 kitöltött kérdőíve is a földön állt felhalmozva a levéltári felbecslés időpontjában - ezt is magukkal vitték a levéltárosok (de a több mint húsz év média- és közvéleménykutatási anyagait, tanulmányait, jelentéseit, külföldi szakanyagait, bizalmas és nyilvános kiadványait nem). A kutatási dokumentumok pedig már összekészítve várták egy raktárban, hogy használt papírként mielöbb a hulladékfelvásárlás helyszínére, a MÉH telepre szállítsák. ${ }^{4}$

Ekkor Vásárhelyi Mária - édesapja, az akkor parlamenti képviselő, a Soros Alapítvány társelnöke, korábban az MTA-Soros Alapítvány Bizottságban Soros György személyes megbízottjaként eljáró Vásárhelyi Miklós kapcsolatait kihasználva - kihallgatást kért az MTA elnökétől, Kosáry Domokostól, és segítségét kérte a kutatási anyagok megmentéséhez. Kosáry ötlete volt az ELTE-hez telepített akadémiai kutatócsoport létrehozása, amely végül MTAELTE Kommunikációelméleti Kutatócsoport (KKCS) néven az ELTE Pedagógiai és Pszichológiai Karának Társadalom- és Neveléslélektani Tanszékéhez kapcsolódva alakult meg, és nemcsak a TK/MKI kutató munkatársainak egy részét vette át, hanem az MKI teljes kutatási dokumentációját és könyvtárát is, amelyek így megmenekültek a leselejtezéstől.

A KKCS fennállása alatt további kutatási anyagokkal járult hozzá a TK/MKI dokumentumhagyatékához (Terestyéni 2005), bár ezek volumene, módszertani palettája eltérő volt a korábbiakétól. A tizenöt fővel induló kutatócsoport létszáma az évek során lecsökkent, s a szervezet végül három kutatóval fejezte be müködését. Amikor bizonyossá vált a KKCs közelgő megszünése, Vásárhelyi Mária ismét lépéseket tett a TK/MKI kutatási anyagának megmentésére.

A selejtezésre váró - egyszer már megmentett - dokumentumokat összegyüjtötte, saját és kutatótársai magángyüjteményéből kiegészítette, az egyetlen példányban lévőkből másolatot készített, és egy-egy példányt félretett a sokszorosított kiadványokból. Ezúttal az OSÁ-t mint a közelmúlt történelmi dokumentumainak megőrzése, feldolgozása és kutathatóvá tétele iránt elkötelezett, magas szakmai színvonalon müködő archívumi intézményt kereste meg szakmai segítségért. Az OSA - tekintettel a dokumentumok maradandó értékére, a közelmúlt magyar társadalmának megismerésére való alkalmasságára, és egyúttal a mai empirikus vizsgálatokkal való összevethetőségére - az anyagot befogadta, megőrizte, feldolgozta és nyilvánosan kutathatóvá tette.

3 A kevés említés között lásd Vásárhelyi Mária (2016).

${ }^{4}$ Valószínűsíthető, hogy a volt munkatársak nemcsak a személyes részvételükkel zajlott vizsgálatok egy-egy példányát, avagy a korszerü módszertani leírásokat, hanem a szervezeti átalakulások, a privatizáció, illetőleg a vezetői levelezés releváns példányait is maguknál tartották. 


\section{TK dokumentumok az OSÁ-ban}

A TK/MKI-tól származó dokumentumok jelentős része formailag és tartalmilag is különbözött a szokásos levéltári iratoktól (talán ez is közrejátszott az Országos Levéltár érdektelenségében). A 3. ábra egy sokszorosított kérdőív címlapjának részletét mutatja, a 4. ábrán egy mátrixprinterrel kinyomtatott „leporelló” látható, az 5. ábra pedig két bizalmas kiadvány, a halványkék borítójú, kizárólag az MSZMP KB Agitációs és Propaganda Osztálya engedélyével megismerhető, számozott példányokban nyomtatott „zárt kiadványát”, alatta pedig a rózsaszínü borítójú, kevésbé szigorúan titkos jelentések egyik példányát ábrázolja - egyik sem sorolható a hagyományos levéltári dokumentumok körébe.

\section{3. ábra}

Sokszorositott kérdöív címlapja

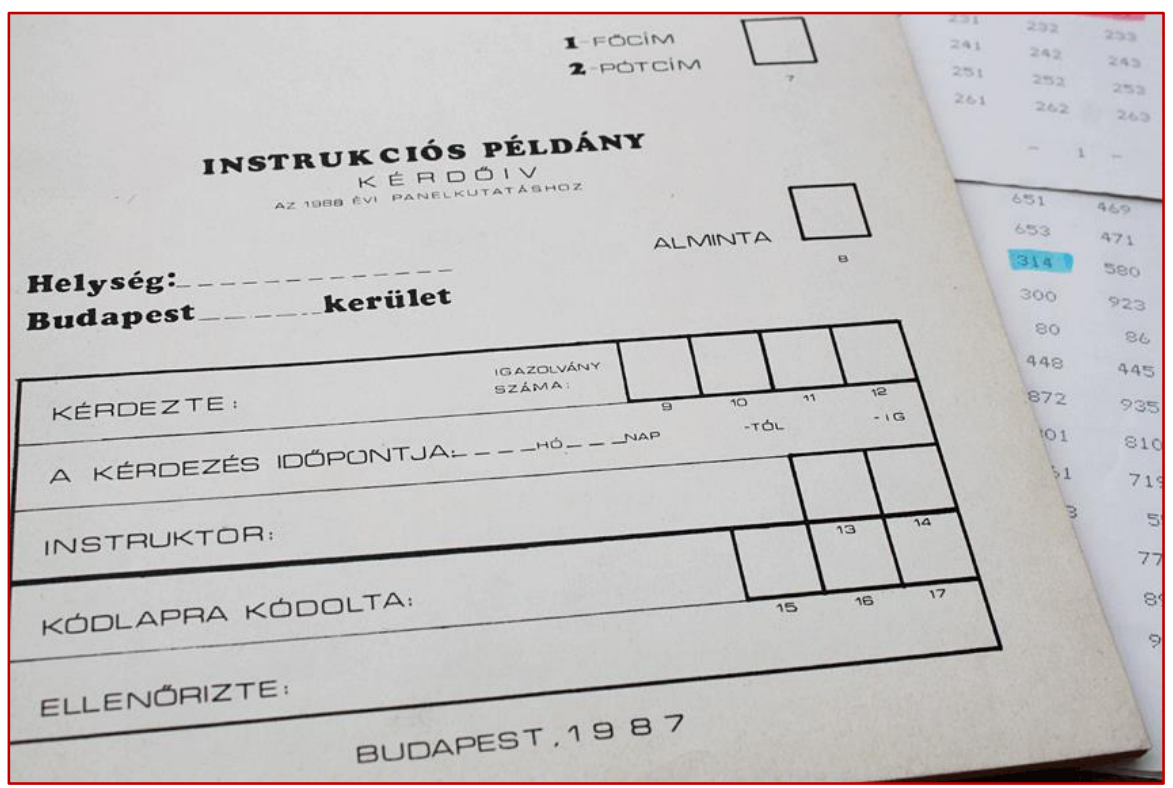

\section{4. ábra}

Számitógépes ,,leporelló” alapmegoszlásokkal

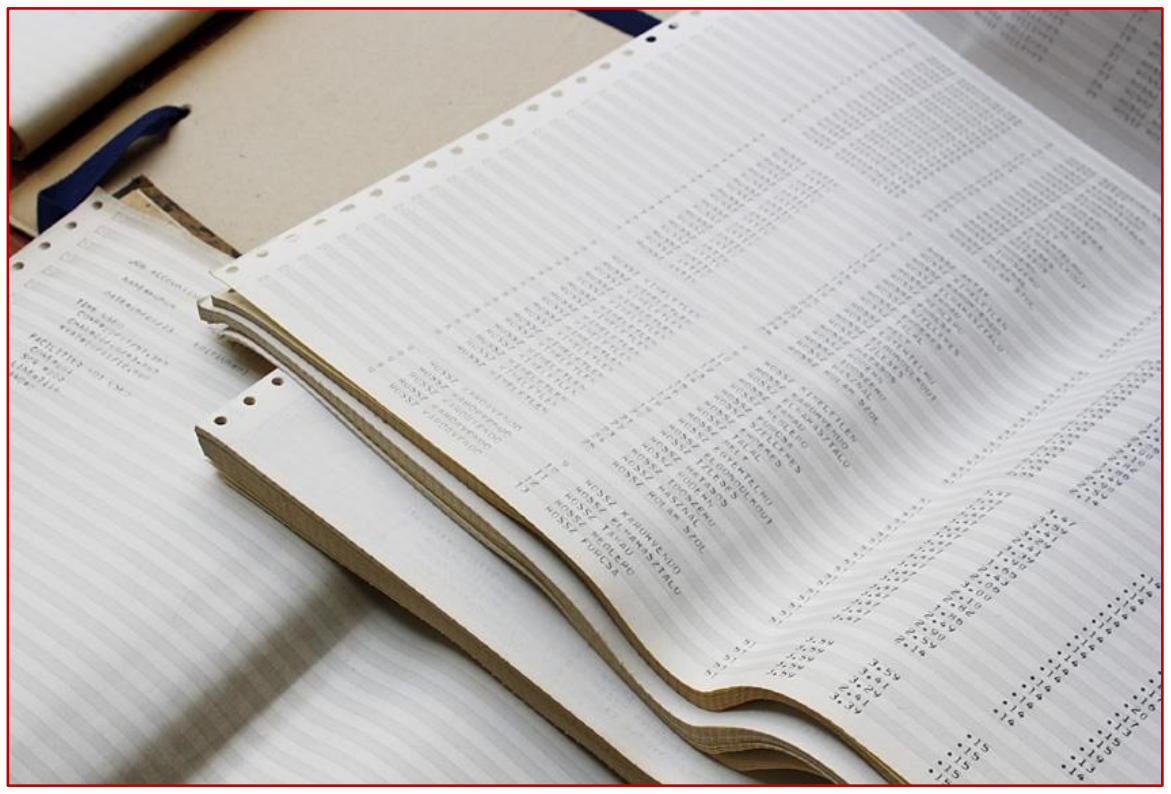




\section{5. ábra}

\section{Bizalmas jelentések}

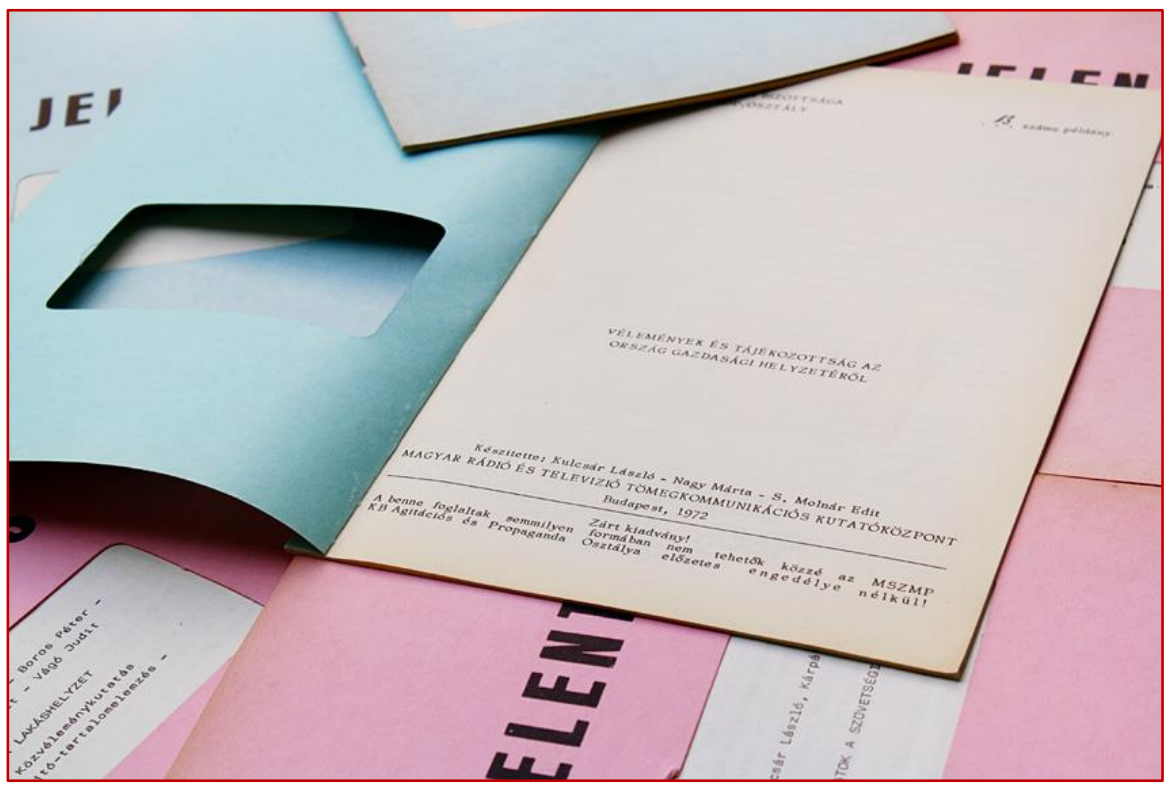

Az már a fondstruktúra ${ }^{5}$ kialakításának kezdetén nyilvánvalóvá vált, hogy az anyag rendezésének nem az MKI (megszünéskori vagy korábbi) szervezeti struktúráján kell alapulnia, hanem az intézmény tevékenységi körein, kutatási produktumain. Több érv is szólt emellett: egyfelöl az intézmény fennállása során a szervezeti struktúra többször is lényegesen megváltozott, egységek jöttek létre, olvadtak össze, az egyes egységek feladatai, hatáskörei változtak, így a szervezeti felépítést követő hagyományos fondstruktúra nem adott volna egységes képet az intézet fö tevékenységéről, a kutatásról; másfelől a fontosabb kutatási és ügyviteli dokumentumokat több szervezeti egység is formálisan és informálisan megkapta, így ezek fölösleges duplumok vagy többespéldányok formájában terhelték volna az archívum feldolgozókapacitását és kutatóit egyaránt; ${ }^{6}$ a döntő érv pedig az volt, hogy az Archívum számára a legértékesebbek maguk a kutatások, azok koncepciója, megvalósításuk, feldolgozásuk, publikálásuk folyamata, a vizsgálatok adatai és eredményei voltak. Ezt a megközelítést már az iratanyag részletesebb ismerete nélkül felállított kezdeti elképzelés is tükrözi, amit változtatás nélkül közlünk (6. ábra).

A megvalósított rendszer tagolása láthatóan leegyszerüsödött (7. ábra): a három $s u b$ fonds ${ }^{7}$ - a kutatások, a kiadványok és az intézménytörténeti iratok kategóriája - ugyan változatlan maradt, az alattuk lévő szinten azonban a sorozatok száma lecsökkent. Beláttuk, ${ }^{8}$ hogy

5 A fond (az összetartozó dokumentumállomány levéltári alapegysége) iratainak intellektuális rendezését, leírását, kereshetőségét és kutathatóságát szolgáló hierarchikus rendszer.

${ }^{6}$ A jövő teljesen digitalizált archívumaiban az ilyen dokumentumok csak egyszer szerepelnének az adatbázisban, de minden olyan szervezeti egység kutatásakor, amelynek köze volt a szóban forgó dokumentumhoz, a dokumentum onnan is elérhető lenne, így teljes képet adva az adott szervezeti egység müködéséről.

7 Magyar terminológiával ,állag”. Az OSA a nemzetközi archívumi gyakorlatban elfogadott angol megnevezéseket alkalmazza belső rendszerében és nyilvános katalógusában.

${ }^{8}$ A többes szám első személy használatát indokolja, hogy a szerző az OSA munkatársa, a TK/MKI anyag kurátora. 
a közvélemény-, média- és egyéb kutatásokat nem lehet dokumentumszinten szétválasztani, és a kutatások írásos eredményeit is a hozzáférhetőségük, és nem a müfajuk szempontjából osztottuk sorozatokra (belső használatú, bizalmas és nyilvános anyagok ${ }^{9}$ ); adminisztratív iratmásolat pedig csak elvétve fordult elő a dokumentumok között, ezért ezek sorozatokra bontása nem volt indokolt.

\section{6. ábra}

Fondstruktúra kezdeti elképzelés

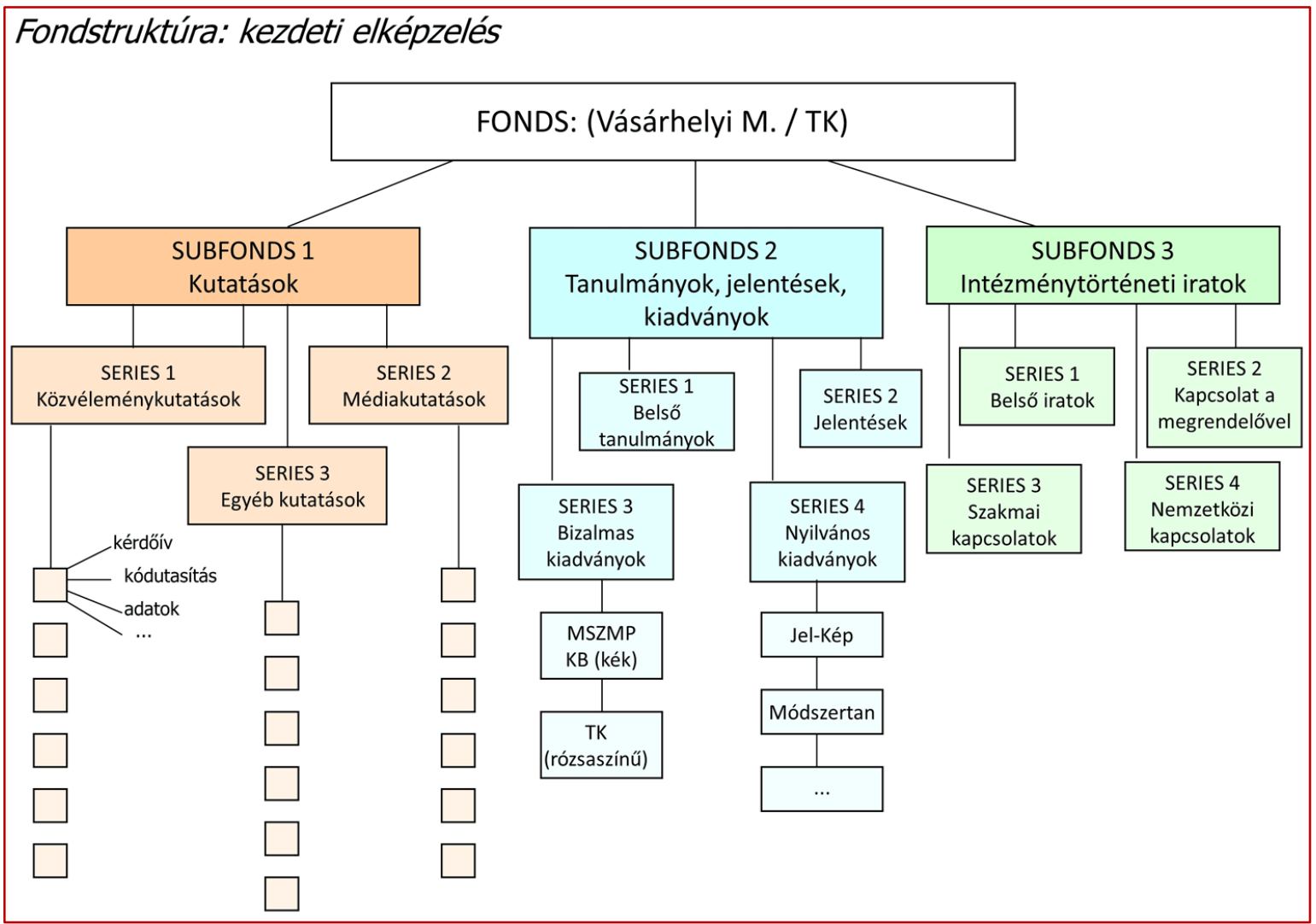

Az átvett anyag feldolgozását és kutathatóvá tételét az OSA prioritásnak tekintette, $\mathrm{s}$ így az archívumi kapacitások és munkafolyamatok szempontjából igen rövid idő alatt elvégezte a dokumentumok fizikai és intellektuális rendezését, részletes kétnyelvű leírását és kereshetővé tételét az OSA online katalógusában. A 2013. áprilisában rendezett „TK 3.0 - avagy hazudtak-e az emberek a Kádár-rendszerben?" címủ konferencia célja az volt, hogy a kutatókat és a nagyközönséget megismertesse a frissen kutathatóvá vált dokumentumkorpusszal. (8. ábra $)^{10}$

9 A nyilvános kiadványok - mint a Jel-Kép folyóirat - az OSA könyvtári katalógusában váltak kereshetővé.

${ }^{10}$ A gyüjtemény kis mértékü bővülése azóta is folytatódik, volt TK/MKI munkatársak adományai révén (legutóbb például Szekfü András anyagát bevételezte az archívum). Az OSA nyitott a volt munkatársak, utódszervezetek által megőrzött, esetlegesen felbukkanó történeti értékủ dokumentumok további befogadására. 


\section{7. ábra}

Fondstruktúra: a megvalósitott rendszer ${ }^{11}$

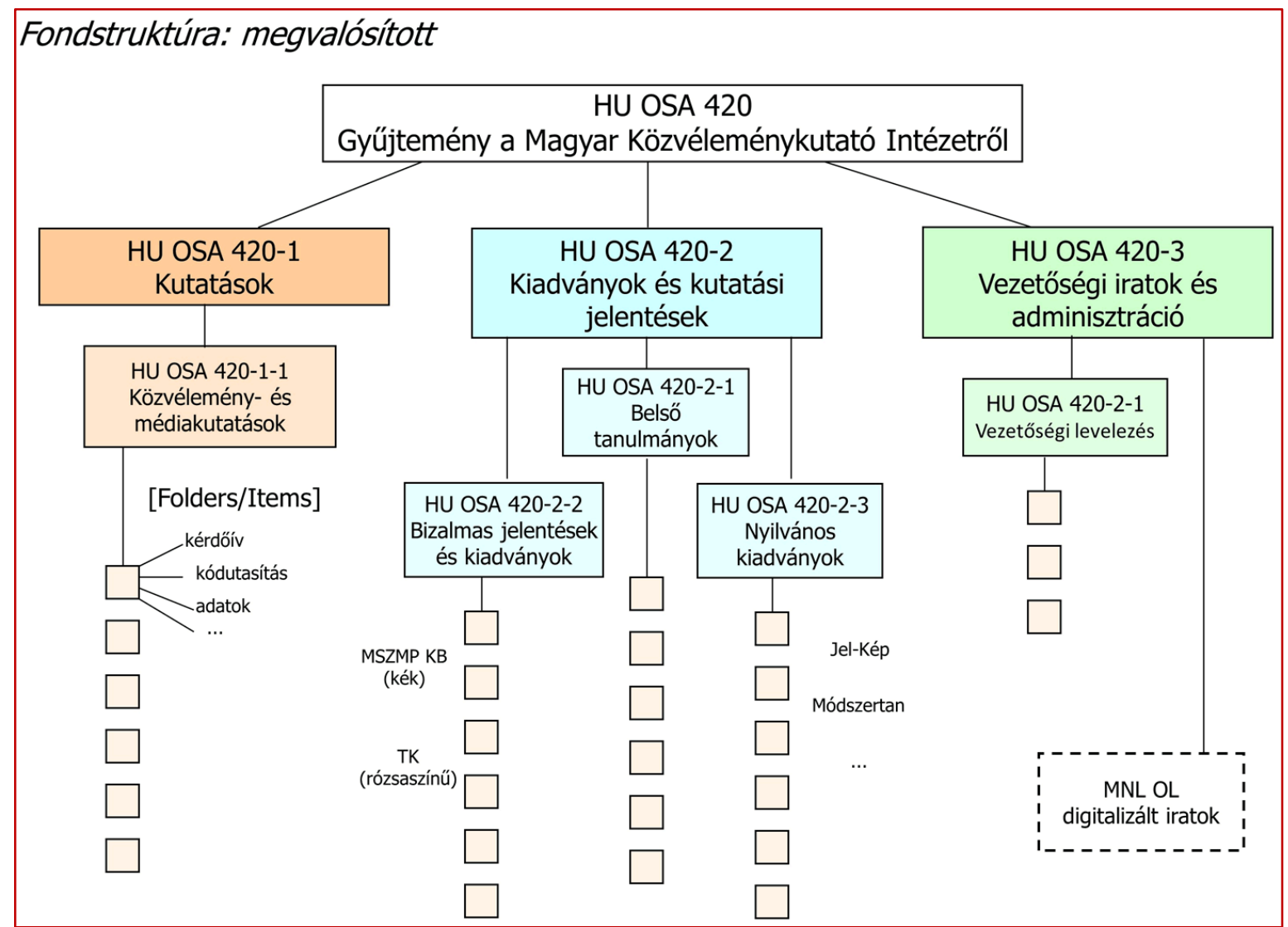

8. ábra

A kutathatóvá válás bejelentése, 2013. április 29., OSA

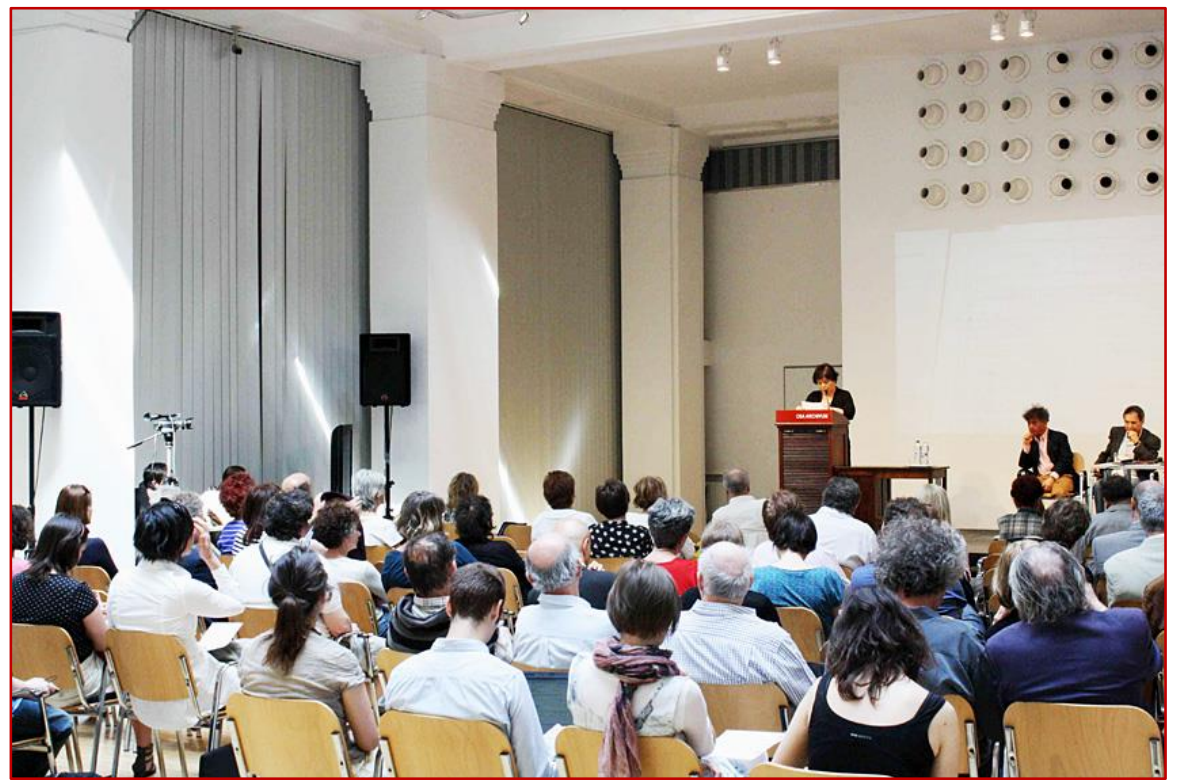

${ }^{11}$ A fond elnevezése az intézmény megszünéskori nevét tükrözi, alegységeinek számozása pedig a nemzetközi levéltári szabványoknak megfelelö hierachikus rendszert. 
Az intézmény történetének egyes aspektusait és a dokumentumok sorsát bemutató elöadások mellett külön figyelmet keltettek azok a prezentációk, amelyek a korábbi vizsgálatok adatait összevetették a mai adatokkal, és így a közvélemény hosszabb távú változásaira mutattak rá. ${ }^{12}$ Ezek az adatok nemcsak a TK/MKI által végzett elemzésekböl, tanulmányokból voltak kinyerhetők, hanem azokból a nyers adatokból is, amelyek - sajnos nem teljeskörüen - digitális formában fennmaradtak az intézet kutatásaiból. A poros floppylemezek tartalmának kimentéséhez az OSA munkatársai speciális „mentőállomást” állítottak össze, megfelelő meghajtóval és (fizikai) adatrekonstruálásra szolgáló szoftverekkel. A kiolvasott fájloknak csak egy része volt alkalmas közvetlen felhasználásra az MKI-ban és számos más kutatóhelyen adatelemzésre használt SPSS programcsomaggal (ún. *.SAV fájlok), a többi esetben csak adatokat tartalmaztak (*.DAT fájlok), amelyek értelmezéséhez némi informatikai jártasság, a vonatkozó vizsgálatok dokumentumai (kérdőív, kódutasítás) és legfőképpen kutatói elszántság és kitartás szükséges. Ezt a munkát támogatandó, Susánszky Pál közremüködésével egy „Útmutató digitális adatok helyreállításához - kutatóknak" címủ segédletet készítettünk, amelynek egy-egy részlete a 9. és a 10. ábrákon látható (Susánszky 2013).

\section{9. ábra}

Az adatrekonstruálási segédlet részlete (fájlformátumok)

\begin{tabular}{|c|}
\hline $\begin{array}{c}\text { Útmutató } \\
\text { digitális adatok helyreállításához - kutatóknak } \\
\text { Susánszky Pál }\end{array}$ \\
\hline $\begin{array}{l}\text { Ha Ön talál egy olyan kutatást az OSA Archivum „TK” állományában }{ }^{1} \text { (HU OSA } 420 \\
\text { Gyüjtemény a Magyar Közvéleménykutató Intézetröl), amelyet szívesen elemezne vagy } \\
\text { újraelemezne, azonban nem áll rendelkezésre az SPSS programcsomag által megnyithaté } \\
\text {.SAV fájl, vagy nincsenek felcimkézve az egyes változók és azok értékei, de megvan a } \\
\text {.DAT fájl, amely az adatokat tartalmazza, akkor ennek az útmutatónak a segitségével ném } \\
\text { idö- és energiaráforditással pótolni tudja a hiányzó információkat és elemzésre alkalmas } \\
\text { formára tudja alakitani az adatállományt. Ehhez az SPSS szintaxisának ismeretére var } \\
\text { szükség. }\end{array}$ \\
\hline $\begin{array}{l}\text { Alapvetöen két esetben van szükség az adatok rekonstrukciójára: 1) amikor a SAV fájl } \\
\text { amit megnyitott, hiányos, vagyis nincsenek benne a címkék, 2) amikor nincs egyáltalán a } \\
\text { kutatáshoz hozzárendelve SAV fájl, azonban van hozzá DAT állomány. }\end{array}$ \\
\hline 1. Az adatállományok (fájlok) fajtái \\
\hline DAT állomány: Ez a fájl tartalmazza az empirikus adatokat, a válaszadók kódolt válaszait. \\
\hline 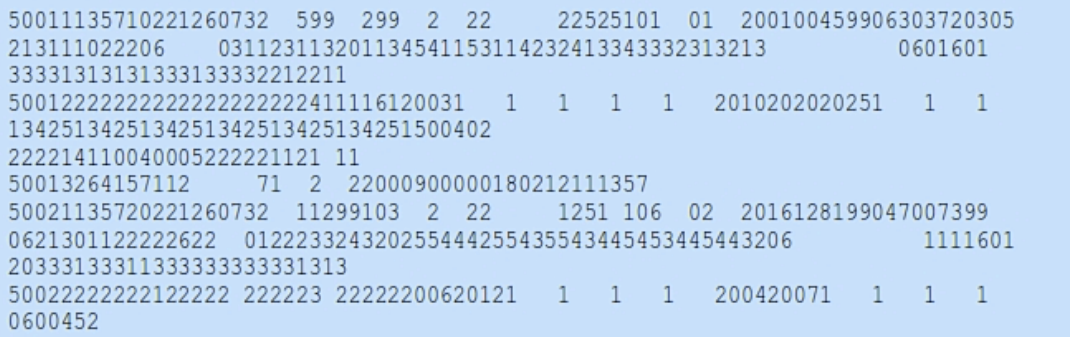 \\
\hline $\begin{array}{c}\text { 1. ábra: Egy DAT állomány részlete. A táblázatot soronként kell olvasni, egy sor egy } \\
\text { megkérdezett válaszait tartalmazza. }\end{array}$ \\
\hline
\end{tabular}

12 „A mai cigányellenesség és antiszemitizmus előképei a Kádár-korszakban” (Krekó 2013); „Kapcsolatok, erőforrások, interakciók" (Kmetty 2013). 
Ha tehát egy kutató egy konkrét vizsgálat publikált eredményeit ismerve, avagy az OSÁ-ban megismerhető kutatási anyagai alapján szeretné újraelemezni az eredeti adatfelvétel nyers adatait - és ehhez rendelkezésre állnak az ezt tartalmazó fájlok - a két adatforrás: egyfelől a kérdőívek, kódutasítások, másfelől az adatfájlok összevetésével, az adatrekonstruálási útmutató segítségével hozzájuthat az adatokhoz. Az így megkapott adatokat természetesen nemcsak az eredeti elemzési módszerekkel, hanem más módszerekkel is vizsgálhatja, és a megfelelő matematikai-statisztikai összehangolás után együttesen elemezheti a későbbi vizsgálatok adataival is.

10. ábra

Az adatrekonstruálási segédlet részlete (programozás)

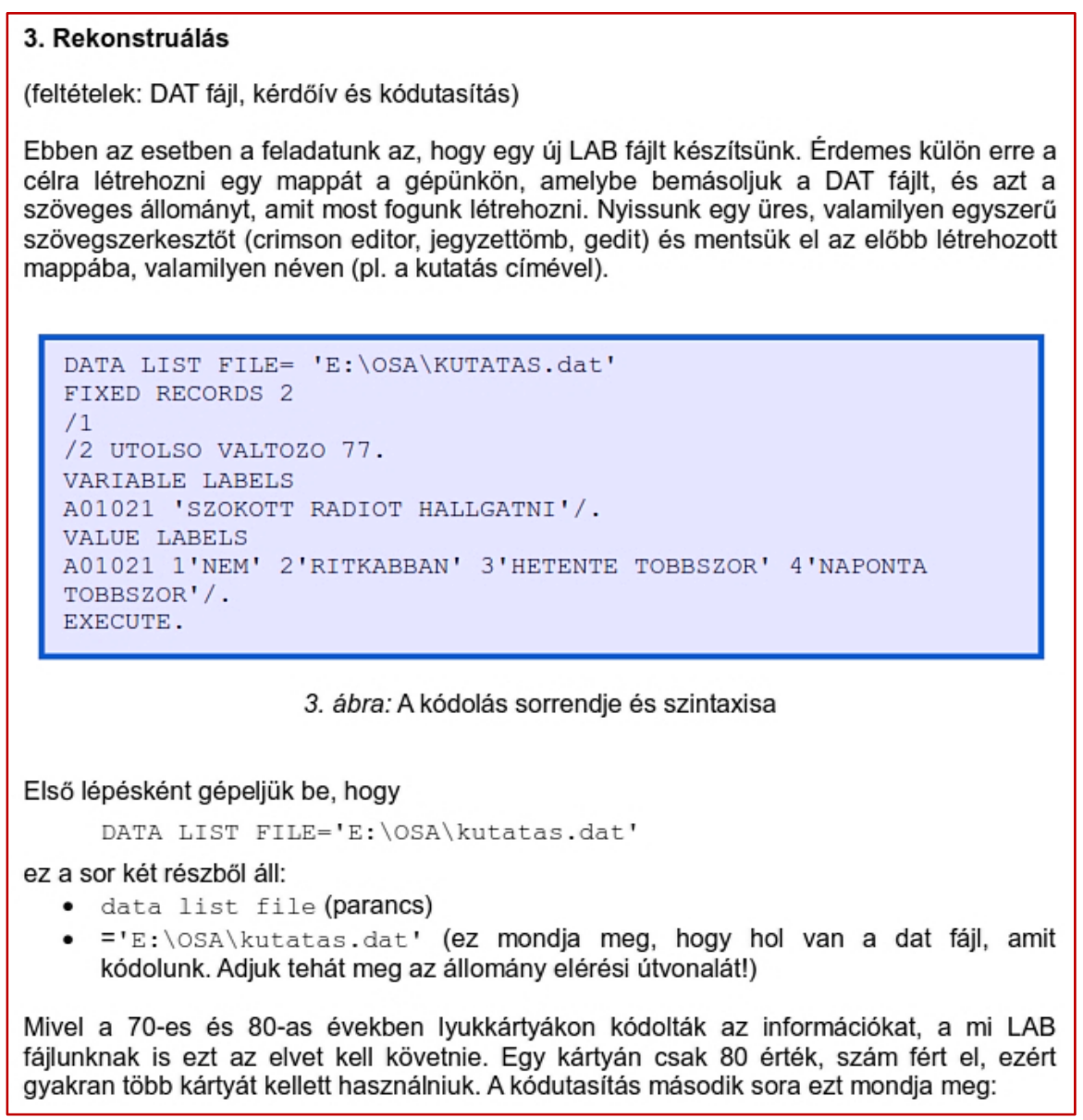

A kutatási anyagok tartós megőrzésének és nyilvánosan kutathatóvá tételének célját tehát az OSA ezzel megvalósította. Úgy gondoltuk azonban, hogy az adminisztratív iratok egy részének ismerete másodlagos forrásként hozzájárulhat a kutatási anyagok értékeléséhez, kontextusba helyezéséhez. Ezek az iratok, mint korábban említettük, az Országos Levéltárba ${ }^{13}$ kerültek. Az OSA egyik deklarált célja, hogy a különböző helyeken őrzött, különbözőképpen kutatható, de összetartozó dokumentumokat egységes (valós vagy virtuális) helyen, egységes leírással tegye kutathatóvá. A TK/MKI esetében ehhez nem volt szükségünk az Országos Levéltárban őrzött összes adminisztratív iratra: az érdekes lehet a TK/MKI kutatási anyagait elemzők számára, hogy milyen időszakban hány kutató dolgozott az intézetben, mennyi volt a szervezet költségvetése, milyen egységeknek milyen feladatuk volt, honnan kapott politikai vagy állami meg-

${ }^{13}$ Mai elnevezésével Magyar Nemzeti Levéltár Országos Levéltára (MNL OL). 
rendelést, utasítást az intézet, de azt, hogy kinek mennyi volt a fizetése, mikor ment szülési szabadságra, vagy hogy mikor milyen irodaszereket vásárolt az intézet, nem tartottuk relevánsnak.

Ezért az Országos Levéltár katalógusában elérhető információk alapján az OSA vezető munkatársai egy előválogatást végeztek a relevánsnak tekinthető dokumentumokról, majd a levéltár kutatótermében - kollegiális segítséggel, az egyéni kutatók számára egy alkalommal kikérhető dobozok számát messze túlhaladó mennyiségben - átnézték és az OSA szempontjai szerint kijegyzetelték a dobozok tartalmát. Az annotált jegyzék alapján az OSA 2014 nyarán együttmüködési megállapodást kötött a levéltárral arról, hogy az OSA szempontjai szerint releváns iratokat az OSA saját eszközein digitalizálja, kutatói számára kutathatóvá teszi, és egyúttal a digitalizált anyagokból átad egy kópiát a levéltárnak. ${ }^{14}$

Mivel a digitalizálandó dokumentumok kivitele az MNL OL épületéből nem történhetett meg (ellentétben a korábbi hasonló együttmüködések gyakorlatával), a levéltár az OSA munkatársának külön kutatószobát bocsátott rendelkezésére, ahová feltelepítettük az OSA tulajdonát képező digitalizáló berendezéseket, és ahol a munkatársunk több hónapon át végezte a kiválogatott anyagok professzionális szkennelését, csoportosítását és az elfogadott konvenció szerinti elnevezését. Megjegyzendő, hogy munkatársunk (esetenként más OSA kollégák segítségével) nem csupán a kiválasztott dokumentumok digitalizálását végezte, hanem a dokumentumok fizikai rendezését is (iratkapcsok, PVC irattartók eltávolítása, duplumok megjelölése stb.), és ezzel jelentősen elősegítette a Magyar Közvéleménykutató Intézet iratainak papíralapú kutathatóságát is az MNL OL épületében.

A digitalizálás volumenét az alábbiakban érzékeltetjük az MNL OL számára készített segédlet alapján. A digitalizált iratanyag a következő fó állományokból áll:

A. Magyar_Kozvelemenykutato_Intezet_scanned_MasterFiles fökönyvtár: 33.676 TIFF fáj1, 7.418 folderben, 149 GB terjedelemben

B. Magyar_Kozvelemenykutato_Intezet_scanned_PDF-high fökönyvtár: 7.043 nagy felbontású PDF fáj1, 7.393 folderben, 27,2 GB terjedelemben

C. Magyar_Kozvelemenykutato_Intezet_scanned_PDF-low fökönyvtár: 7.043 kis felbontású PDF fáj1, 7.475 folderben, 5,42 GB terjedelemben

Az „A” állomány prezervációs célokat szolgál. Az időbeli, szervezési és müszaki körülmények figyelembevételével hozott kompromisszum eredményeképpen a TIFF fájlok nem-veszteségmentes, LZW tömörítéssel készültek, 300x300 DPI felbontásban. Ebben a formátumban minden egyes beszkennelt oldal külön fájlt alkot. A „B” állomány a levéltáros kollégák munkáját könnyítheti meg: a több oldalas dokumentumok egy közös, lapozható PDF fájlba vannak füzve. Ezek a fájlok alkalmasak nagy felületre való kivetítésre is. A „C” állomány elsősorban a kutatók számára készült: a fájlok mérete jelentősen kisebb (hosszanti oldal mérete 1500 pixelben maximalizálva, 72 DPI felbontás), így gyorsabban előhívhatók vagy letölthetők, de a minőségük alkalmas a képernyőn olvasásra.

\section{Kit érdekelnek a múlt adatai?}

Ezt a kérdést általánosságban, és a TK dokumentum- és adathagyatéka vonatkozásában is feltehetjük. Általánosságban egy emlékezetőrző intézménynek - múzeumnak, könyvtárnak, levéltárnak - a legitimációját, voltaképpen létének okát az adja, hogy létezik egy olyan közönsége, amelynek tagjai valamilyen szempontból érdeklődnek a megőrzött tárgyak, képek, ki-

\footnotetext{
${ }^{14}$ Hasonló együttmüködési megállapodást korábban más állami fenntartású szervezetekkel (Magyar Távirati Iroda, Országos Széchényi Könyvtár, Budapest Főváros Levéltára) is kötöttünk, mindkét fél megelégedésére és kölcsönös előnyére.
} 
adványok, dokumentumok, adatok iránt. A szempontok különfélék lehetnek (alap- és alkalmazott kutatás, müvészi inspiráció, politikai ösztönzés, laikus érdeklődés, publikálási törekvések, üzleti érdekek, oktatási követelmények stb.) és az intézmények által kiszolgált közönség összetétele is lényegesen változott az idők során. ${ }^{15}$ Az OSA nemzetközi gyüjtőkörü intézmény jelentős magyar vonatkozású anyaggal, mintegy 70 nyelven született dokumentumállománnyal, kétnyelvü (angol és magyar) honlappal és katalógussal, nemzetközi összetételü - helyben és távoli hozzáféréssel kutató - közönséggel, meghatározott gyüjteményi idősávval (a második világháború utáni időszak történelme) és témakörrel (kommunizmus és hidegháború, emberi jogok). Az archívum legitimációját tehát ennek a látogatóközönségnek az érdeklődése adja. ${ }^{16}$ (Az OSA kutatóinak motivációi, kutatói érdeklődése, az intézményröl és a kutatási körülményekről alkotott véleménye megismerhető a „Why OSA?” [Miért az OSA?] címü rövid audiovizuális beszámolókból, lásd:

https://www.youtube.com/playlist?list=PLW16VxGg82nUkz6LfVzFdk--S_8mWdTA2)

A TK/MKI esetében elsősorban azokat érdekelhetik a megörzött dokumentumok és adatok, akik kutatják

- Magyarország és a szocialista tábor politika- és intézménytörténetét;

- a szociológia mint tudomány fejlődését, a tudástranszfer alakulását;

- a 70-es, 80-as évek és a rendszerváltás társadalmi viszonyait, közvéleményét;

- a mai magyarországi társadalmi viszonyok előképét, a múlttal való kapcsolatát;

- a régi és új adatok összekapcsolását módszertani szempontból;

- a Visegrád Ösztöndíj ${ }^{17}$ valamelyik témakörét. ${ }^{18}$

\section{A mai kutatási lehetőségek}

Összefoglalva az eddigieket, a TK/MKI dokumentum- és adathagyatéka jelenleg az alábbi helyeken és módokon kutatható:

(a) A papíralapú dokumentumok és kiadványok teljesen feldolgozva, nyilvánosan hozzáférhetően kutathatók és másolhatók a Blinken OSA Archívum kutatótermében ${ }^{19}$ és online katalógusában. $^{20}$

(b) A digitalizált intézménytörténeti iratok elöfeldolgozva, de még nem rendezve és leírva az OSA szerverein találhatók; kutathatóságuk feltétele a rendezés és leírás.

(c) A papíralapú intézménytörténeti (valamint személyzeti, pénzügyi és egyéb adminisztratív) iratok a Magyar Nemzeti Levéltár Országos Levéltárában kutathatók.

${ }^{15}$ Archívumi kontextusban lásd erről Székely (2007).

${ }^{16}$ A Blinken OSA Archívum tevékenységének négy fő pillére közül csak az egyik - bár a legfontosabb - az archívum, emellett oktatási, kutatási és kulturális intézményként is müködik.

${ }^{17}$ A Nemzetközi Visegrád Alapítvány által felajánlott ösztöndíjak a Blinken OSA Archívumban kutató szakemberek, művészek és újságírók számára, akik az Archivum anyagának felhasználásával az Alapítvány és az Archívum által megjelölt témakörökben végeznek kutatómunkát, lásd http://www.osaarchivum.org/hu/dolgozz-velunk/osztondijak/visegrad-osztondij.

${ }^{18}$ Az említett „Why OSA?” kutatói interjúk közül lásd Szakál Veronika rövid beszámolóját a TK/MKI anyagban végzett kutatásáról Szakál (2019).

${ }^{19}$ A Blinken OSA Archívum nyilvánosan és ingyenesen látogatható épülete a 1051 Budapest, Arany János u. 32. szám alatt található.

${ }^{20}$ http://www.osaarchivum.org/hu (Gyüjtemény $\rightarrow$ Katalógus). 
(d) A számítógépre vitt adatok megmentett része - föként az intézmény müködésének utolsó szakaszából - kutatható az OSÁ-ban. A fájlok egy része közvetlenül használható, más részüket a kutatónak magának kell rekonstruálnia, amihez gyakorlati útmutató áll rendelkezésére.

(e) Az intézmény történetéröl, müködéséröl, kutatási eredményeinek és adathagyatékának használatáról szóló konferenciaelőadások kisfilmmé szerkesztve megtekinthetők az OSA YouTube csatornáján. ${ }^{21}$

https://www.youtube.com/playlist?list=PLW16VxGg82nUgXYg7Fmz0oiggN9De3hZp

Annak érdekében, hogy az olvasó ne csupán az általános érdeklődés szintjén tájékozódjon a TK/MKI dokumentumainak kutathatóságáról, álljon itt egy rövid gyakorlati útmutató az OSA online katalógusának használatáról.

Először is egy általános gyakorlati tanács: egy szakmailag megbízható, jó belső keresővel rendelkező intézmény anyagait sohase a Google vagy más keresőgépek segítségével keressük! A Google, Bing és hasonló keresők ugyanis találatokat adnak, a belső keresők találatokat plusz kontextust. A kutatót pedig nemcsak a kontextusából kiragadott találat érdekli, hanem annak tartalmi összefüggései is.

Kezdjük tehát az OSA integrált keresőgépének legfelső szintjén:

http://catalog.osaarchivum.org/browse/fondslist, és görgessünk le a 420. fondig! A kis „,+” jelre kattintva kibomlik a fond struktúrája, és a 11. ábrán látható kép áll elénk.

11. ábra

Az MKI fondja a fondlistában

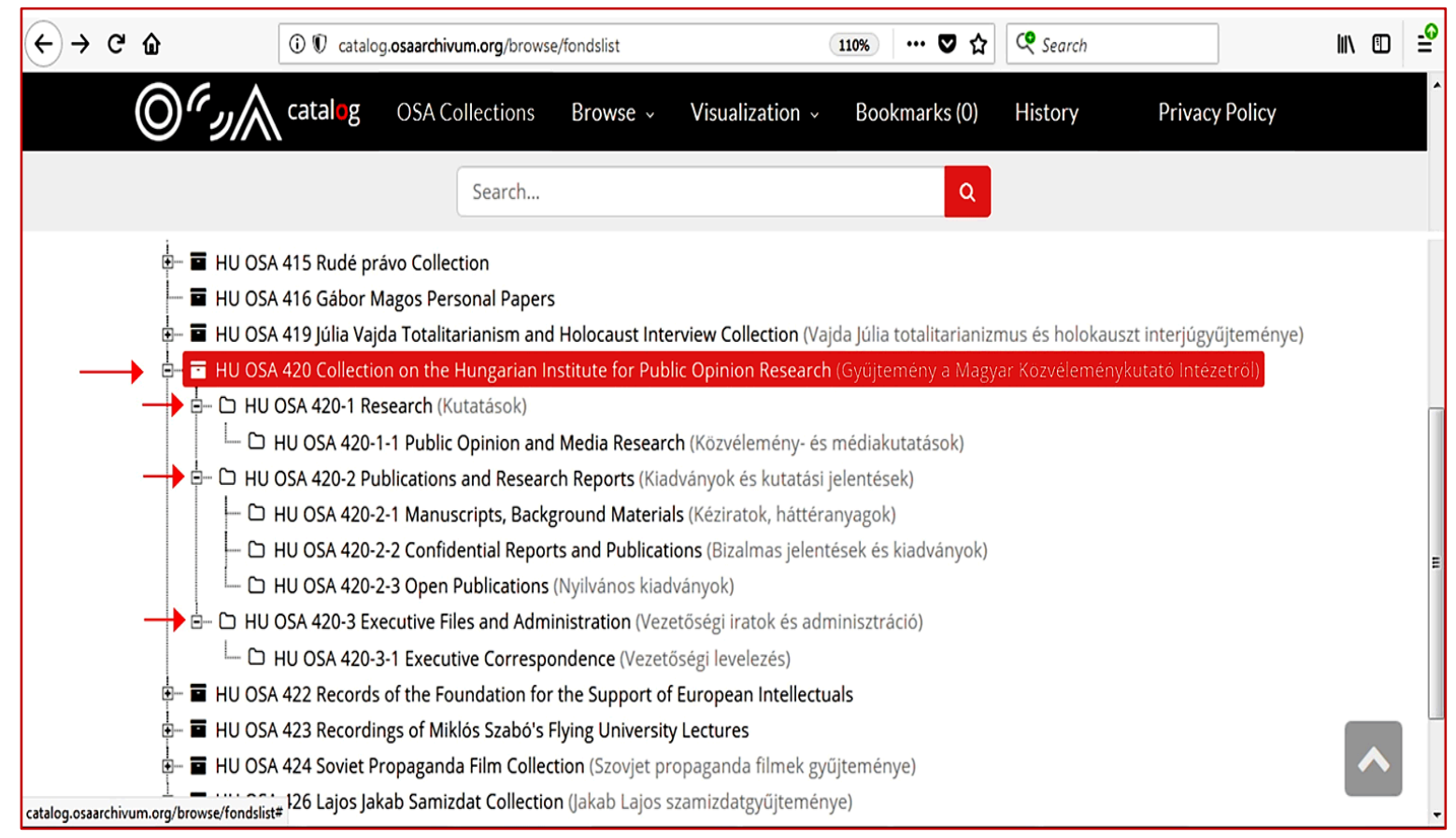

${ }^{21}$ Az OSA YouTube csatornája is kétnyelvü: a magyar és angol nyelvü leírások és további linkek annak függvényében jelennek meg a képernyőn, hogy a felhasználó számítógépén a nyelv a Beállítások/Settings menüpontban magyarra vagy angolra (English US) van állítva. 
Ha rákattintunk a fond nevére, a fond leírását látjuk, alapbeállításként angolul (célszerü mindig magyar nyelvre váltani a nézett oldalt a nyelvválasztóval) (12. ábra):

\section{2. ábra}

Fondszintü leírás a katalógusban

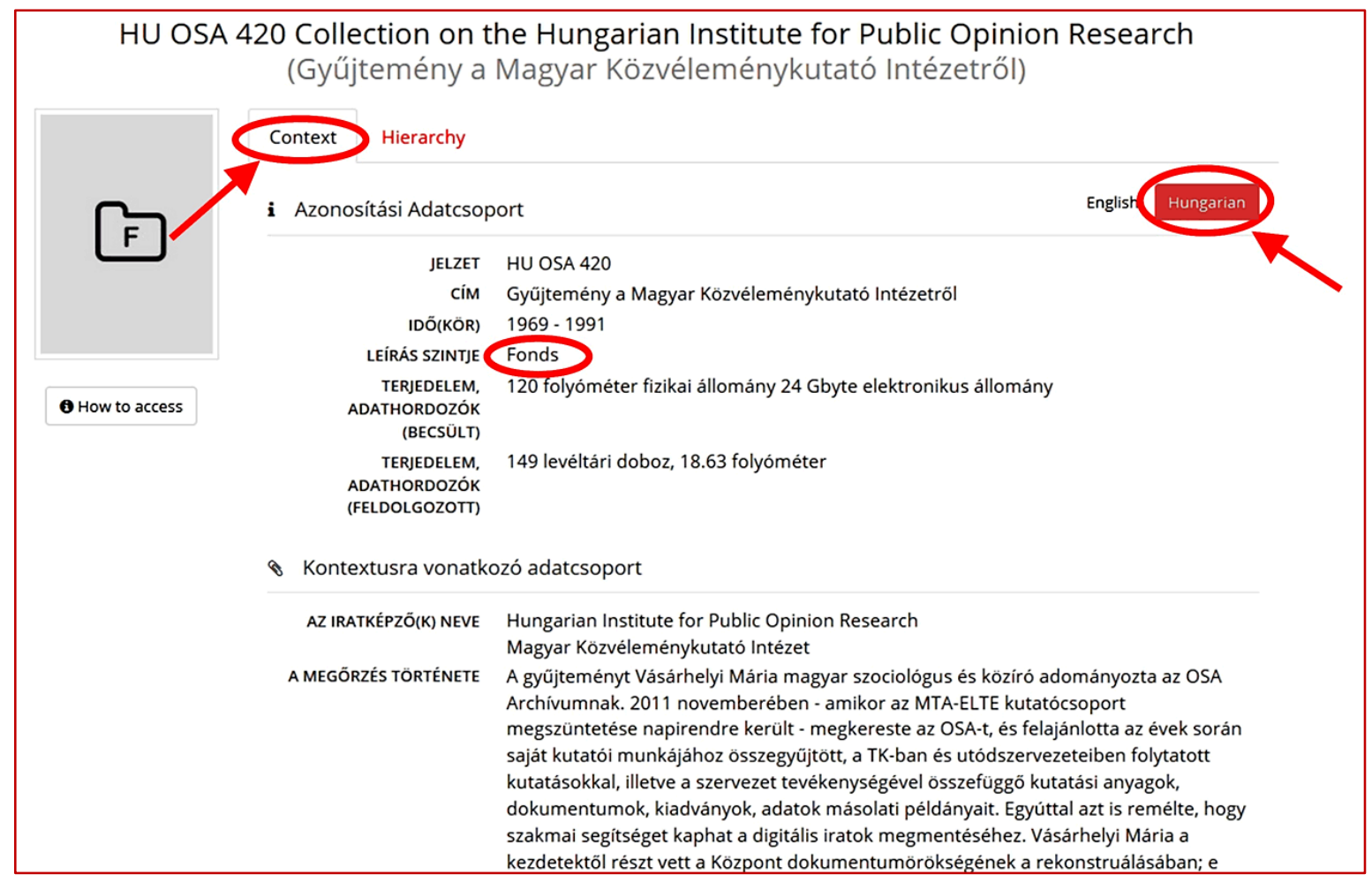

A nemzetközi levéltári leíró szabványoknak megfelelően ${ }^{22}$ a leírás mindig csak az adott egységre vonatkozik, ebben az esetben a fond egészére. Ha alsóbb szintre navigálunk, ott már nem olvasható az, hogy milyen intézmény volt a TK/MKI, és hogyan kerültek a dokumentumai az OSÁ-ba, csak az adott állag vagy sorozat, esetleg egyedi dokumentum leírása látható. Minden szintröl visszaválthatunk a Hierarchy fül segítségével a fondstruktúrához, hogy lássuk, éppen hol járunk a navigációban.

Válasszuk ki a Kutatások állagot: http://catalog.osaarchivum.org/catalog/jD7w7o9b\#hu, itt bőséges információt találhatunk a TK/MKI kutatásairól mindkét nyelven. Megjegyzendő, hogy ennek a fondnak a leírása az általános levéltári szokásokhoz, de még az OSA feldolgozási gyakorlatához képest is igen gazdag. Eggyel lejjebb lépve válasszuk ki ennek az állagnak az egyetlen sorozatát: „Közvélemény- és médiakutatások”

(http://catalog.osaarchivum.org/catalog/O8pMpeWP\#hu). Az ide tartozó leírások elolvasása után kattintsunk a Folders/Items fülre! Erre a lapra jutunk:

http://catalog.osaarchivum.org/catalog/O8pMpeWP\#findingaids. (Természetesen minden felsorolt link közvetlenül is elérhető.) Ezen a lapon dátum és téma szerint, avagy szabadszavas kereséssel találhatjuk meg a keresett anyagokat, a bal oldalon látható jelzet alapján pedig kikérhetjük az adott dobozokat az OSA kutatótermében (13. ábra).

${ }^{22}$ General International Standard Archival Description, ISAD(G); International Standard Archival Authority Record for Corporate Bodies, Persons and Families, ISAAR (CPF) 


\section{3. ábra}

\section{A kutatások listája}

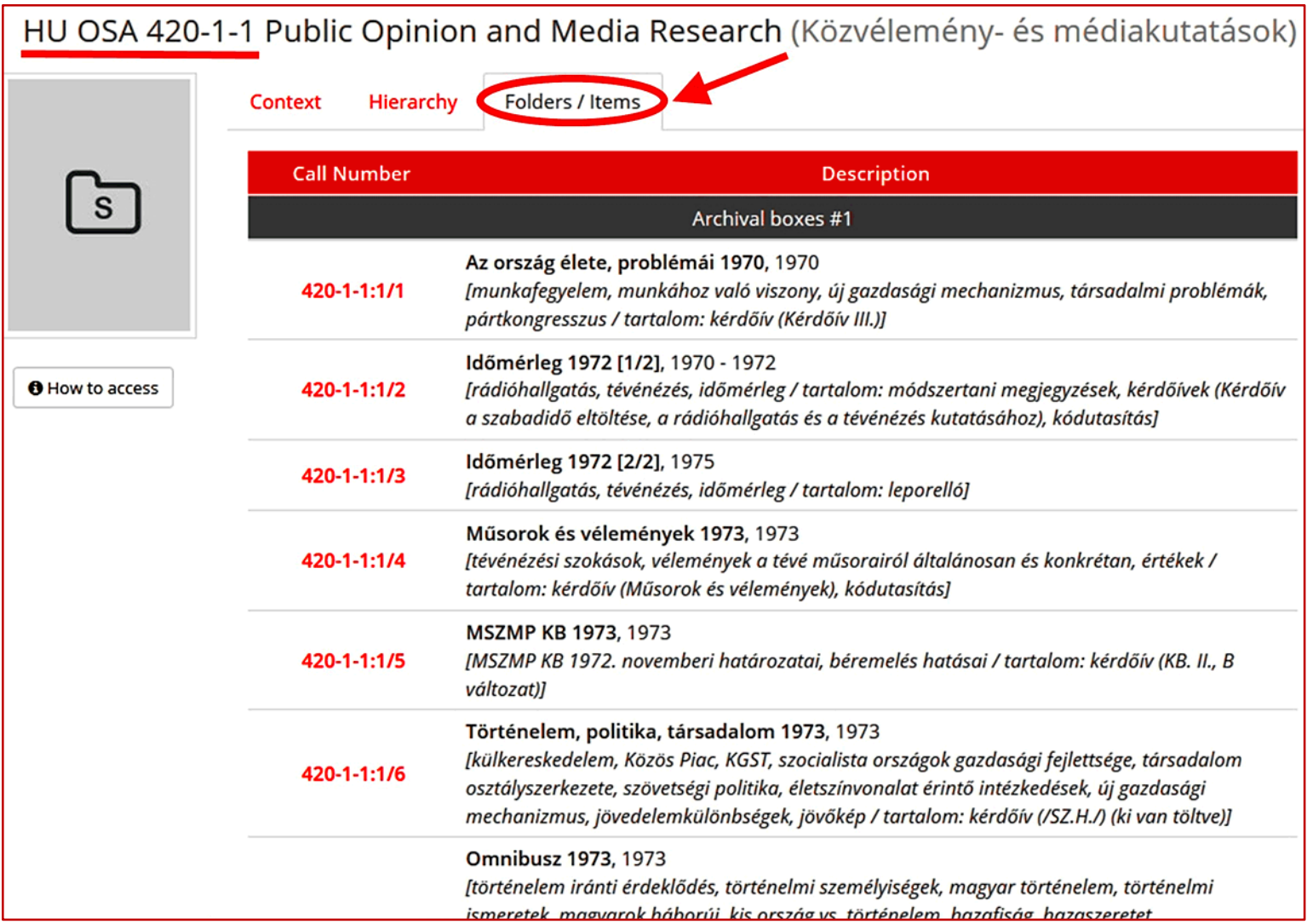

Megjegyzendő, hogy a gyakorlott kutatónak nemcsak hierarchikusan, hanem „keresztirányban" is érdemes vizsgálnia az egyes TK/MKI kutatások dokumentumait. A kutatások megrendelése és finanszírozása az intézménytörténeti iratok között tárható fel, a koncepció kidolgozása és a vizsgálat lebonyolítása a Közvélemény- és médiakutatások sorozat dokumentumai között, a nyers adatok a megmaradt digitális anyagok között ismerhetők meg; az eredmények először gyorsjelentésekben és belső tanulmányokban jelentek meg, majd bizalmas kiadványokban, utána pedig fokozatosan „lecsurogtak” a nyilvánosan elérhető kiadványokba is („Kiadványok és kutatási jelentések” állag sorozatai). Ehhez az OSA integrált keresőjének különféle funkcióit, szürőit használhatjuk.

\section{Utószó: lesz-e TK 4.0?}

A Tömegkommunikációs Kutatóközpont, későbbi nevén Magyar Közvéleménykutató Intézet, amely jelentős belső szabadsággal, de korlátozott nyilvánossággal müködő intézmény volt, végül egy ingyenesen és nyilvánosan kutatható archívum révén vált megismerhetővé a mai kutatók és érdeklődők számára. Dokumentum- és adathagyatéka több évtizedes hányattatás és kétszeri megmentés után, fizikailag és intellektuálisan rendezve, részletesen leírva, segédletekkel ellátva került a Blinken OSA Archívum állományába.

A Vera és Donald Blinken Nyílt Társadalom Archívum a Közép-európai Egyetem szervezeti egysége. Az Egyetem, mint köztudott, az elmúlt évek magyarországi politikai támadásai miatt az ország elhagyására kényszerült; a 2019-2020 tanév újonnan felvett hallgatói már az egyetem új bécsi kampuszán iratkoztak be és ott kapják majd meg diplomájukat. Még nem eldöntött kérdés, hogy a jövőben a budapesti kampusz milyen oktatási-kutatási szerepet 
tölt be (amelynek megörzését az egyetem erkölcsi kötelességének tartja). Többen megkérdezték emiatt, hogy vajon az OSA gyüjteménye és infrastruktúrája „,biztonságban van-e”, nem kell-e tartani az elköltöztetésétől, és a Tömegkommunikációs Kutatóközpont iratai szempontjából lesz-e TK 4.0?

Legjobb tudomásunk szerint - már amennyire ma Magyarországon jósolni lehet - az OSA tartósan Budapesten marad, gyüjteménye ${ }^{23}$ biztonságban van. Ha újabb verzióváltásra kerül sor a közeljövően, az legfeljebb TK 3.1 jelölést kaphat - akkor, amikor megtörténik az Országos Levéltár anyagából digitalizált iratok leírása és kutathatóvá tétele.

\section{IRODALOM}

Kmetty Zoltán (2013) Kapcsolatok, erőforrások, interakciók. A TK 3.0 - avagy hazudtak-e az emberek a Kádár-rendszerben? c. konferencián elhangzott előadás, 2013. április 29., OSA. https://www.youtube.com/watch?v=11QmT4r2YA\&list=PLW16VxGg82nUgXYg7Fmz0oiggN9De3hZp\&index=4

Krekó Péter (2013) A mai cigányellenesség és antiszemitizmus előképei a Kádár-korszakban. A TK 3.0 - avagy hazudtak-e az emberek a Kádár-rendszerben? c. konferencián elhangzott előadás, 2013. április 29., OSA.

https://www.youtube.com/watch?v=32Vv_I6gfx0\&list=PLW16VxGg82nUgXYg7Fmz 0oiggN9De $3 \mathrm{hZp} \&$ index $=4 \& \mathrm{t}=0 \mathrm{~s}$

Lukáts János (é.n.) A Tömegkommunikációs Kutatóközpont kiadói tevékenysége 1969-1991.

Susánszky Pál (2013) Útmutató digitális adatok helyreállításához - kutatóknak. Blinken OSA Archívum.

Szakál Veronika (2019) Public Opinion Research in the Kádár Era. Why OSA? Research in the archives, Blinken OSA Archívum.

https://www.youtube.com/watch?v=ciMClQX8kAw\&list=PLW16VxGg82nUkz6LfVz Fdk--S 8mWdTA2\&index $=4 \& \mathrm{t}=0 \mathrm{~s}$

Székely Iván (2007) A négy archívumi világkép. Információs Társadalom VII. évf. 3. szám. 15-46. old. https://www.infonia.hu/digitalis_folyoirat/2007_3/2007_3_szekely_ivan.pdf

Székely Iván (2018) TK 1.0, 2.0, 3.0 - avagy egy intézmény tanulságos metamorfózisai. A magyar szociológia az ezredfordulón c. konferencián elhangzott elöadás, 2018. május 10., Wesley János Lelkészképző Főiskola.

https://archive.org/details/A_magyar_szociologia_az_ezredfordulon_2018/00015_Tama sPal.MTS

Terestyéni Tamás (2005) MTA-ELTE Kommunikációelméleti Kutatócsoport. http://www.communicatio.hu/mktt/dokumentumok/konferenciak/2005/kutatohelyek/mt a_elte kek.htm

${ }^{23}$ Benne a Szabad Európa Rádió és Szabadság Rádió mintegy 2.500 folyóméter terjedelmű anyagával, amely jelentősen hozzájárult ahhoz, hogy az OSA a kommunizmus és a hidegháború globálisan egyik legnagyobb archívumává váljon, és amely az Egyesült Államok tulajdona, és amelyet az USA illetékes szervei 50 évre letétbe helyezték az OSÁ-ban, budapesti elhelyezést kikötve. 
Terestyéni Tamás (2009) Volt egyszer egy Tömegkommunikációs Kutatóközpont... TK 40 A Tömegkommunikációs Kutatóközpont (1969-1991) helye és jelentősége a tudományban, a politikában és a médiakultúrában c. konferencián elhangzott előadás, 2009. október 1., Magyar Rádió.

http://www.communicatio.hu/mktt/hirek/konferenciak/2009/tk40/nyitoeloadas.htm Nyomtatásban: Jel-Kép 2009. 3-4. 15-20.

Vásárhelyi Mária (2016) Média- és közvélemény-kutatás a Kádár-korszakban. Médiakutató XVI. évf. 1. szám, 93-96. old.

https://mediakutato.hu/cikk/2016_01_tavasz/06_media_es_kozvelemenykutatas.pdf 